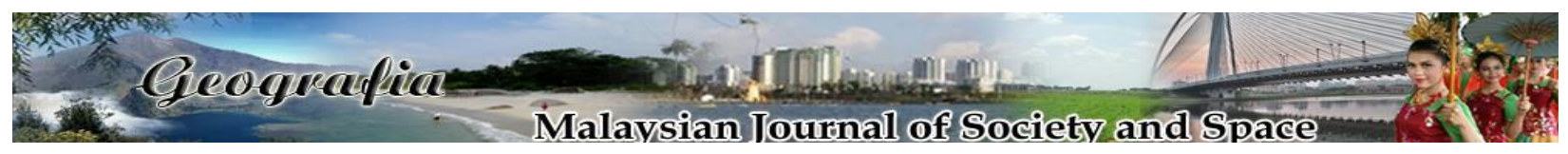

\title{
The nature of political representation: Voters' perception towards the role of political representation
}

\author{
Rosyidah Muhamad ${ }^{1}$, Ummu Atiyah Ahmad Zakuan ${ }^{2}$, Nazli Aziz ${ }^{1}$, Siti Aisyah Saat ${ }^{1}$, Rohana Ahmad ${ }^{1}$ \\ ${ }^{1}$ Faculty of Business, Economy and Social Development \\ Universiti Malaysia Terengganu \\ ${ }^{2}$ College of Law, Government and International Studies \\ Universiti Utara Malaysia \\ Correspondence: Rosyidah Muhamad (email: rosyidah@umt.edu.my)
}

Received: 24 February 2021; Accepted: 23 May 2021; Published: 27 August 2021

\begin{abstract}
There is a wide spectrum in academia that representatives of the citizens should act in line with the interests of those who are being represented. Knowledge about citizens' preferences, however, is still limited in the field of political representation in Malaysia. This paper examines the MPs' roles as the citizens' representatives in Malaysia from the perspective of the citizens themselves. Based on the survey $(n=598)$, the voters' preferences that are being analysed through three models of representative-delegates, trustee and partisan. The research findings indicate that the constituents place a high priority on the MPs in bringing development to the constituency rather than in the law making and advocating. To this end, more expectations are for the MPs assemble to delegate model. Citizens perceive the MPs' main role as a legislator as a minor role. This perception could reflect on the political situation in Malaysia. Accordingly, this paper suggests that the MPs should focus on their main functions in policy making, to participate in the parliamentary debates actively and to represent their constituencies at the national level. The MPs should take the local issues for national policies implementation to be contextualized in their respective local constituencies.
\end{abstract}

Keywords: Citizens perception, constituencies, member of parliament, Malaysian politics, political representative, role of the representative

\section{Introduction}

Parliament is an important body in a democratic country. Through its representatives, the Members of Parliament (MPs), the concerns and interest of the people are channelled. Hence, as the representatives of the people MPs are highly crucial in setting the issues that are debated as well as lobbied, which eventually are to be passed as laws or policies in the countr. However, with the 
complexity and interdependency of modern day government administration, the MPs roles have multiplied especially in the developing countries. The formal role of the MPs is as a legislator (Arkirav O., 2019), however, the MPs role as the legislator has been intertwined with various informal roles. Consequently, the MPs multiple roles have reduced their ability to be fully committed as the law makers (Abdul Rashid, 2009; Aziz, 2012). The intertwined roles of political representatives have contributed to the debates among scholars. Most of the literature on political representational roles concentrate on formal and informal roles where in particular a representative should act as delegates, trustee and also as the partisan.

The notion of representation usually refers to MPs who should represent the people, which usually covers three categories of interest. The first is to represent the nation as a whole irrespective of their constituents. This is usually referred to as delegates. The second is constituents in which the representative should represent those who vote for them. The MPs should act in favor of their constituents' interests. This is referred to as the trustee. The third is the party which refers to the MPs as party politicians where they should follow the party decision. This is referred to as the partisan. Correspondingly, these created conflict on the representational roles of the MPs. On the one hand, MPs should represent the people either the nation or their constituents. On the other hand, MPs should also follow their political party goals and objectives as it was crucial for reelection. Therefore, it is important to examine the role of representation from the voters' point of view.

The relationship between representatives and voters has caught much attention among scholars, particularly from the MPs' own view on their roles (e.g., Wright, T., 2010; Campbell, R \& Lovenduski, J, 2015). However, voters' preferences on the representative roles are still scarce and are biased towards the representatives' process in the US (Mendez-Lago \& Martinez, 2002). Given the scarcity of research in a developing and non-Western country such as Malaysia, this study has filled the gap by analyzing the views of voters regarding the role of political representation. Moreover, this study will produce rich knowledge of voters towards their MPs and this could benefit the government in better policy implementation in the country as well as in the field of political sciences.

\section{Models of political representations}

There are extensive studies on the definition of political representation, yet few can agree on one particular definition. The simplest definition of political representation by Hanna Pitkin (1967) is, to make present again; this is referring to the political activity to translate the citizens' voice into the public policy making. Political representation occurs when political actors speak, advocate, symbolize and act on the behalf of others in the political arena. As such it refers to the political assistance for the citizens in the democratic world. Political representation can be regarded as the effort of the parliamentarian, "to build more inclusive, deliberative and engaged relationship with the publics" (Orr \& McAteer, 2004: 133). For example, Heywood (2002: 224) noted that "as a political principle, representation is a relationship through which an individual or group stands for, or acts on behalf of a larger group of people." Representation by the parliamentarian can occur if there is evidence of consultation as well as engagement in the decision-making and local policy formulation that are promoted by the parliamentarian.

The relationship between a representative and the citizens is very crucial. Pitkin (1967) in her important study on representation has described the relationship of the representative and voters from the continuum of 'stand for' on one hand, and 'act for' on the other hand. A 
representative who 'stand for' something or someone else acts as the representative of what he or she represents rather than doing something (Pitkin, 1967, 61), while an 'act for' representative is the representative who is not only representing he or she but who also acts for the sake of the voters. As mentioned earlier, the existing works on political representation are mostly concentrated on the three basic models of representation and voters, i.e., delegates-trustee-partisan. The complexity of political scenarios could contribute to the changing of political representative roles from delegates to trustee to partisan.

\section{a) Delegates}

Delegates are model representatives who abide by the expressed preferences of their constituents. James Madison describes the representative government as, "the delegation of the government...to a small number of citizens elected by the rest." (Tiffany, 2007). Madison suggests having a diverse and large population as a way to decrease the problems with bad representation. In other words, the preferences of the represented can partially safeguard against the problems of faction. These delegates act only as a mouthpiece for the wishes of their constituency and have no autonomy to act on the behalf of the whole nation (Tiffany, 2007).

Searing (1985) argues that the Westminster MPs are very devoted to their constituencies. The MPs listen carefully to the issues that are raised and emerge at their constituencies. They will try to sort out the problems of the individual and advocate the constituents' rights. MPs who have received complaints from their constituents will report and spend hours in order to solve the issues in the ever-increasing amount of constituency casework (Lusoli \& Ward, 2004). Brouard et al. (2013) points out that MPs in France focus more on constituency works than on the parliamentary works. They claim that $85 \%$ of the backbenchers gives priority to the constituency role rather than the legislative role in the parliament.

\section{b) Trustee}

The trustee of representation is a model on how we should understand the role of representatives, and it is frequently contrasted with the delegate model of representation. Constituents elect their representatives as 'trustees' (or 'entrust' them) for their constituency. These 'trustees' have sufficient autonomy to deliberate and act in favor of the greater common good and the national interest, even if it means going against the short-term interests of their own constituencies. The model provides a solution to the problem of uninformed constituents who lack the necessary knowledge on issues to take an educated position. By contrast, in the delegate model, the representative is expected to act strictly in accordance to a mandate from the represented.

As such, a trustee as a Member of Parliament must act as a legislator to legislate on behalf of the nation based on the MP's own judgement. The trustees, to some extent, must have autonomy to deliberate and act in favor of the national interest vis-à-vis the interests of their own constituency (Fox \& Shotts, 2009). In fact, they may act as an advocator or oversee the government in enabling the MPs to perform their roles as legislators effectively. They must also profess to have different knowledge of national and global issues. These acquired knowledge is necessary on order to allow them to participate in the parliament proceedings more effectively. Any MPs should be able to table a bill, draft a proposal or debate on amendments. As the elected representatives, the MPs role in the parliament should be 'neutral' as representing the interests of citizens in general. The mandate that is given by the citizens will allow the MPs to exercise their power in the parliament. 
They have the prerogative to support, oppose or remain neutral in any deliberation of bills that are tabled. However, often the MPs are lacking in knowledge to undertake the task of law-making effectively. Hence, many MPs perceive that the legislative role is not their main role (Brouard, Costa, Kerrouche \& Schnatterer, 2013).

Historically, the roles of delegates and trustee have been seen as complex and sometimes as intertwined. These are not mutually exclusive but rather MPs may act as both a trustee and also as a delegate depending on the circumstances (Rahman, 2013).

\section{c) Partisan}

A partisan refers to a representative who acts on behalf of their party and who always supports their political party. At the beginning of the twentieth century, political parties were established to mobilize voters and then turned into a practice of representation of political party (Manin, 1997). The political culture of advancing the party's interests over the citizens has contributed to the changing role of the MPs (Bengtsson \& Wass, 2011). The MPs started to change their roles, where instead of representing the constituents and a nation as a whole, the political party gradually control the whole process of representation (Mendez-lago \& Martinez, 2002). The party begins to control the MPs, who need to coordinate their actions with the party policy. Consequently, the voters no longer vote for the candidate whom they believe in, instead they start to vote for the party (Manin, 1997). Marsh and Norris (1997) claim that the practice is very common in a country which has strong and competitive political parties i.e., the citizens vote for the political party instead of the candidates. The elections would be a competition between various political parties instead of individual candidates. Hence, the constituency services that are provided by the MPs reflect the partisan roles of the MPs based on the party's needs and objectives

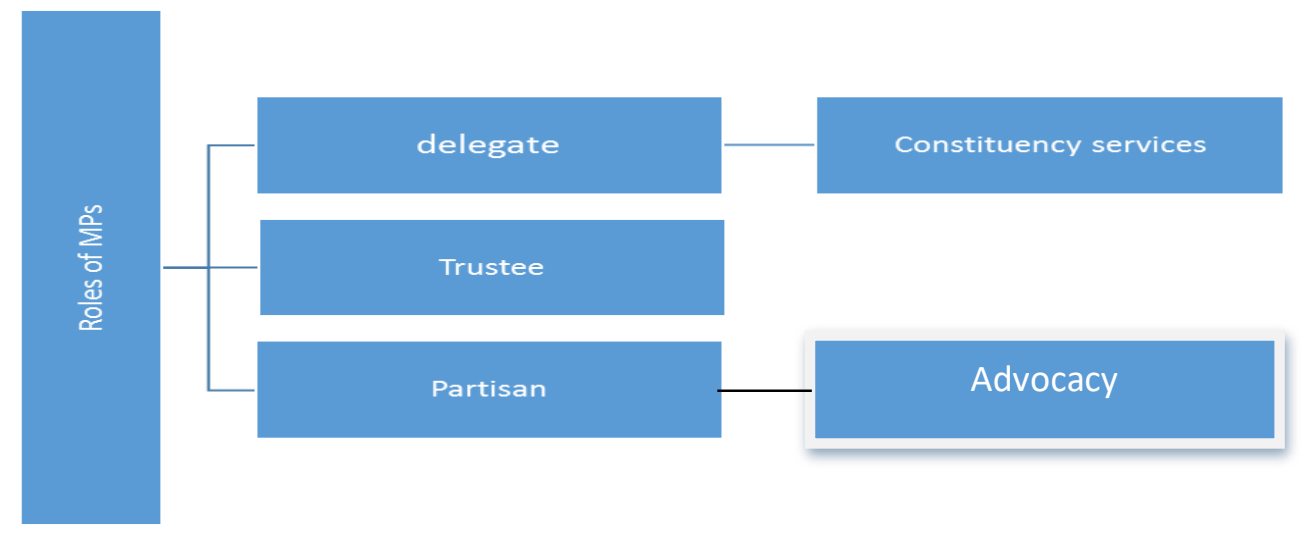

Figure 1. The role of MPs in theoretical perspective.

\section{Context of the study}

After independence in 1957, Malaysia was characterized by ethnic divisions. The ethnic divisions and the division of power among the elites led to the formation of the first alliance party comprising the United Malay National Organisation (UMNO), the Malaysian Chinese Association (MCA) and the Malaysian Indian Congress (MIC). This alliance depended on a coalition of ethnically based parties, the Barisan Nasional (BN).

The policymaking style of bargaining failed spectacularly after a bloody riot in May 1969. 
According to Crouch (1996), the tension between the Malays and Chinese had been growing because of economic and social imbalances. After the 1969 riot, various policies were formulated, the most significant of which was the New Economic Policy (NEP). The NEP's main goals were to reduce and eventually to eradicate poverty, and in accelerating the process of restructuring the Malaysian society in order to correct economic imbalances. It aimed to give Malays and Bumiputera more economic power. With that, the role of the ruling BN, especially UMNO, became more dominant following the NEP, especially in terms of economic development. Various economic development agencies were established at the federal and state levels to help the people, particularly the Malays. The NEP appeared to have achieved its targets, particularly in reducing poverty. Indeed, the identification of the ethnic group label with economic function had also decreased. By 1990, the Malaysian society was recognised as an advanced, middle-income country. At the same time, the implementation of the NEP resulted in a sharp increase in Malays' participation in both middle- and urban-based, working-class occupations (Crouch, 1996).

All these developments led to the BN becoming a dominant political actor, which remained unchallenged and in power for almost 61 years after independence. Despite the remarkable economic growth, the ruling BN consolidated its power and strengthened authoritarian rule. The dominant position of the $\mathrm{BN}$ through the decades enabled it to diminish the centrality of the parliament, to continuously gain a two-thirds majority in parliament that enabled the ruling $\mathrm{BN}$ to amend the constitution to meet its interests (Hwang, 2003).

After the late 1990s, the Parliament regained some relevance in the system, especially after the BN failed to gain the absolute majority of seats in the Dewan Rakyat at the 1999 General Election. The Malaysian society had started to show signs of revolt against the government, especially after the dismissal of the Deputy prime Minister- Anwar, in 1997. A reform movement has arisen and since then, dissenting voices have been vibrant. The 1999 election results indicated that the BN had lost support among the Malay community. Subsequently, in the 2008 and the 2013 General election, the BN suffered its worst results. Correspondingly, this was the context in which the survey for this article was based and administered to the citizens.

Acknowledging the limited participation of parliament in policy decisions, the Malaysian MPs still play an increasingly significant role in linking central decision-makers to the constituents. Several studies have pointed out the MPs' role. Malike (2017) has noted that the constituency services that are provided by the MPs role as the informal role. Meanwhile, Aziz (2012) suggests that the MPs tasks in providing and delivering constituency service to be similar to that of the social workers. He (2012) elaborates that the involvement of MPs in social activities are a symbolic gesture to the citizens, where the MPs symbolic role inspires and motivates the citizens as an accumulative perception of the presence of political representative in their everyday life. Accordingly, the MPs in Malaysia devote a lot of time to solve local issues especially in rural constituents. Ummu Atiyah (2010) highlights that the female parliamentarians have found difficulties to balance their roles as the MPs as well as to cover and deliver constituency activities at the constituency levels. They have to spend more time with the people including attending weddings, funerals, newborn celebrations and so on. The engagements in the constituency role vary, to the extent that the citizens have expected their MPs to solve problems such as drain clogs, a missing identity card, a snake in the house, a toothache and so on. This becomes more difficult since the public has little knowledge of the MPs roles. Similarly, Searing (1985) points out that the MPs in the West are also been considered as the welfare officers.

Significantly, the role of MPs as a legislator remains insignificant. In practice, the Attorney General Office or respective ministry drafts a bill before debating in the parliament. From the GE1 
to the GE13, the role of the MPs as the legislator especially those in the opposition parties had been systematically curbed and reduced because of the executive dominance amongst the MPs of the cabinet members in the Dewan Rakyat (House of Representatives) of the Malaysian Parliament (Aziz, 2012). This was an obstacle to the MPs' ability to effectively voice out the citizen concerns in the parliament. Although the MPs raised citizens' concerns in the Dewan Rakyat, they did not have the power to influence the final decision of the government's cabinet. There are not many parliamentary committees that are being appointed to study the proposed bills or government agenda, with the exception of several committees such as the Committee of Selection, the Public Account Committee, the Standing Order Committee, the House Committee and Committee of Privileges, all of which are set up in order to examine some related matters. It is common that the draft of a bill is drafted by the Attorney General Office or respective ministry and then, to be debated in the parliament which comprises all of the MPs. According to Ummu Atiyah (2014), in her study on female representatives in the Dewan Rakyat, the latter has argued that one of the main obstacles to have an effective debate of an issue is due to the lack of expertise views on the issues concerned. This is due to the lack of or inexistence of a certain committee to scrutinize the issue deeply and critically, thus, the issue is being debated in the whole house.

As such, this shows that it is common to say that parties play a central role in the process of political representation in Malaysian or that parties are more important than individual politicians. However, although many studies have already shown this, few analyses have actually examined the empirical data to measure the manifestation of this domination of parties in the way the role of the representatives is conceived as delegates-trustee-partisan from the voters' perspective.

\section{Methodology}

This study aims at examining the perception of the constituents towards their MPs and their expectations of their political representatives. In analysing the data, a descriptive technique through frequencies is used to interpret the raw data. The sample was purposive sampling in Kuala Terengganu as it is a suitable case study due to the fluctuation in its election result. Based on four series of elections in Terengganu in 1999, 2004, 2008 and 2013, the results were not consistent as in the federal government; UMNO is no longer dominant in Terengganu. Both parties, namely, UMNO and PAS as oppositions have an equal opportunity to win in the election. Therefore, this is an interesting case study.

The respondents have been chosen based on the criteria of having voted in the past election and are of the age above 21 as this is the eligible age to vote. There were 94,406 eligible voters in Kuala Terengganu. The sample of this study is determined based on the Krejcie and Morgan's sample size calculation table. The total sample size was 598 respondents, which was higher that the sample provided by Krejcie and Morgan. Hence, this will make the data more reliable. The data was collected from $1^{\text {st }}$ June until $30^{\text {th }}$. December 2017 as there was no national election during this period, and it was selected to obtain a relatively normal picture of the citizens' perspective towards their representatives.

The representative roles that have been examined are based on the voters' perception and are identified to be the most relevant within Malaysian politics. The main arching question that is asked here is whether the voters' views are related to the MPs roles. The respondents were given a set of questionnaires comprising three parts; Part A: Demographic details; Part B: Information 
of their respective MPs; and Part C: Their hopes towards their respective MPs. The data were analyzed using SPSS quantitative software.

\section{Results and Discussion}

\section{Demographic analysis of the respondents}

In this study, age, education, gender, and occupation are the important variables for the demographic in order to analyze the constituents' perception. The variables affected the perception on the MPs roles, which will be detailed in the other findings below. In this study, the sample of the gender for both sexes is almost equal. The 307 respondents (51.3\%) and 291 respondents $(48.7 \%)$ are males and females, respectively. The majority of the age range is 20-30 years old. The data indicate that 219 respondents $(36.6 \%)$ and 147 respondents $(24.6 \%)$ are in the age range of 20-30 years old and 31-40 years old, respectively. Meanwhile, 110 respondents $(18.45 \%)$ are in the age range of 41-50 years old and 83 respondents (13.0\%) are 51-60 years old. Thirty (5.0\%) and nine respondents $(1.5 \%)$ are in the age range of 61-70 years old, and 71 years old and above, respectively. Those voters within the age range of 61 years old and above are the least represented because of the difficulty to interview them as respondents; this golden age group is very skeptical about the project.

In understanding the role of the political representative, the level of education is one of the important factors that influences the perception of the voters towards the MPs roles in Malaysia. A majority of the respondents have received a formal education, with $49.8 \%$, who have completed secondary school; $19.6 \%$ and $16.1 \%$ have obtained a diploma and a degree, respectively. The constituents with the formal education are able to show a greater awareness, engagement and understanding of the current political situations. To them, a proper formal education provides the MPs with a better understanding of the socioeconomics and social development of reality.

In addition, the social background of the respondents is also an important dimension, in particular the occupation. There is equal distributions of occupation sectors among the respondents, i.e., $23 \%, 24 \%$ and $26 \%$ of the respondents are in the private sector, public sector and business, respectively. The remaining respondents are house wives $(12 \%)$, pensioners $(4 \%)$, the unemployed $(5 \%)$, and others $(6 \%)$. In terms of income, most of the respondents earn within the range of RM901-RM1,500 (28\%) and RM1,501-RM3,000 (23\%) monthly. That means 51\% of the respondents falls under the B40 category. Only 2\% of the total respondents earn RM5,000 and above. A striking feature of the income is that $22.4 \%$ or 134 respondents are dependents of the head of the household.

\section{Citizens' understanding of the MPs roles}

The level of awareness of the voters regarding the roles of the MPs is also investigated in this study. Figure 2 shows that a majority of the respondents $(65 \%)$ are aware of the MPs' roles in Malaysia. 


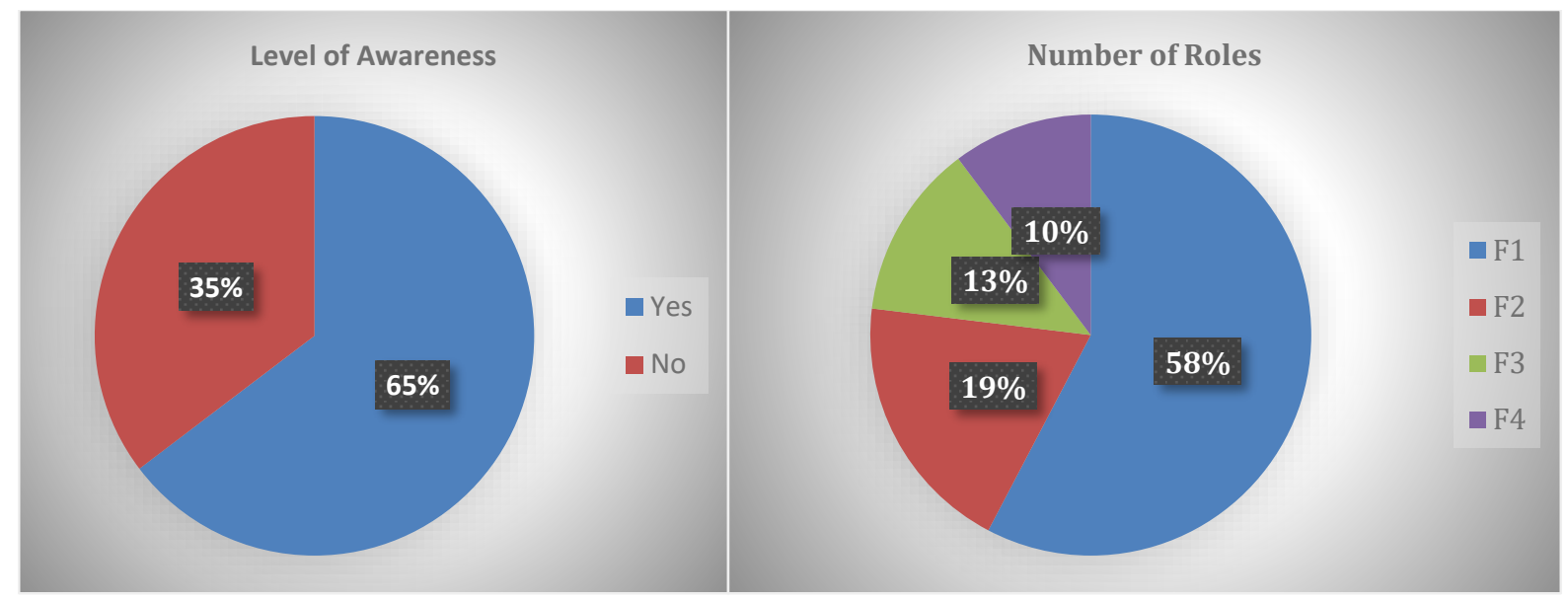

Figure 2. Level of awareness and types of MPs functions.

However, the level of awareness among the constituents varies. The finding shows that the constituents provide different answers of the MPs roles. 58\% of the respondents believes that the MPs only have one role. While $19 \%$ of them mentions two roles and $13 \%$ suggests three roles. The remaining respondents of $10 \%$ believe that the MPs have four roles as is illustrated in Figure 2. In this study, this shows that the constituents are not fully aware of the multiple roles of the MPs as a majority of them have identified that the MPs only have one role. Their attitude may also be linked to the lack of knowledge about what the MPs do and how the political institution work.

As mentioned earlier, demographic variables do influence the level of awareness of the voters in identifying the MPs roles. Education, age and gender show a significant relationship to the level of awareness among most of the constituents on the MPs roles in Malaysia. Table 1 shows that those who have higher education are more aware of the roles of their MPs. Eighty percent of the voters who can identify the MPs roles are degree holders in the age range between 30 and 40 years old. The age group of 51 to 60 years old also shows a higher level of awareness of the MPs roles. Finding indicates that male voters are more aware of the MPs roles as compared to female voters.

Table 1. Level of awareness about the roles of MPs by age and educational status.

\begin{tabular}{|c|c|c|c|c|c|c|c|c|}
\hline \multirow[t]{2}{*}{ Education } & \multicolumn{2}{|c|}{$\begin{array}{c}\text { Level of } \\
\text { awareness }\end{array}$} & \multirow[t]{2}{*}{ Age } & \multicolumn{2}{|c|}{$\begin{array}{c}\text { Level of } \\
\text { awareness }\end{array}$} & \multirow[t]{2}{*}{ Gender } & \multicolumn{2}{|c|}{$\begin{array}{c}\text { Level of } \\
\text { awareness }\end{array}$} \\
\hline & Yes & No & & Yes & No & & Yes & No \\
\hline \multirow[t]{2}{*}{ Primary School } & 15 & 35 & \multirow[t]{2}{*}{$20-30$} & 100 & 119 & \multirow[t]{2}{*}{ Male } & 204 & 103 \\
\hline & $30 \%$ & $70 \%$ & & $45.6 \%$ & $54.4 \%$ & & $66.3 \%$ & $33.7 \%$ \\
\hline \multirow[t]{2}{*}{ Secondary School } & 104 & 194 & \multirow[t]{2}{*}{$31-40$} & 97 & 50 & \multirow[t]{10}{*}{ Female } & 134 & 157 \\
\hline & $35 \%$ & $65 \%$ & & $65.7 \%$ & $34.3 \%$ & & $46.2 \%$ & $53.8 \%$ \\
\hline \multirow[t]{2}{*}{ Certificate } & 11 & 17 & \multirow[t]{2}{*}{$41-50$} & 53 & 57 & & & \\
\hline & $40 \%$ & $60 \%$ & & $53.8 \%$ & $46.2 \%$ & & & \\
\hline \multirow[t]{2}{*}{ Diploma } & 63 & 54 & \multirow[t]{2}{*}{$51-60$} & 53 & 30 & & & \\
\hline & $54 \%$ & $56 \%$ & & $63.4 \%$ & $36.6 \%$ & & & \\
\hline \multirow[t]{4}{*}{ Degree } & 77 & 19 & $61-70$ & 12 & 18 & & & \\
\hline & $80 \%$ & $20 \%$ & \multirow{3}{*}{70 above } & $41 \%$ & $59 \%$ & & & \\
\hline & & & & 3 & 6 & & & \\
\hline & & & & $35 \%$ & $65 \%$ & & & \\
\hline
\end{tabular}


In order to analyze the constituents' perception, the respondents had been asked to choose the main role of the MPs, as shown in Figure 3.

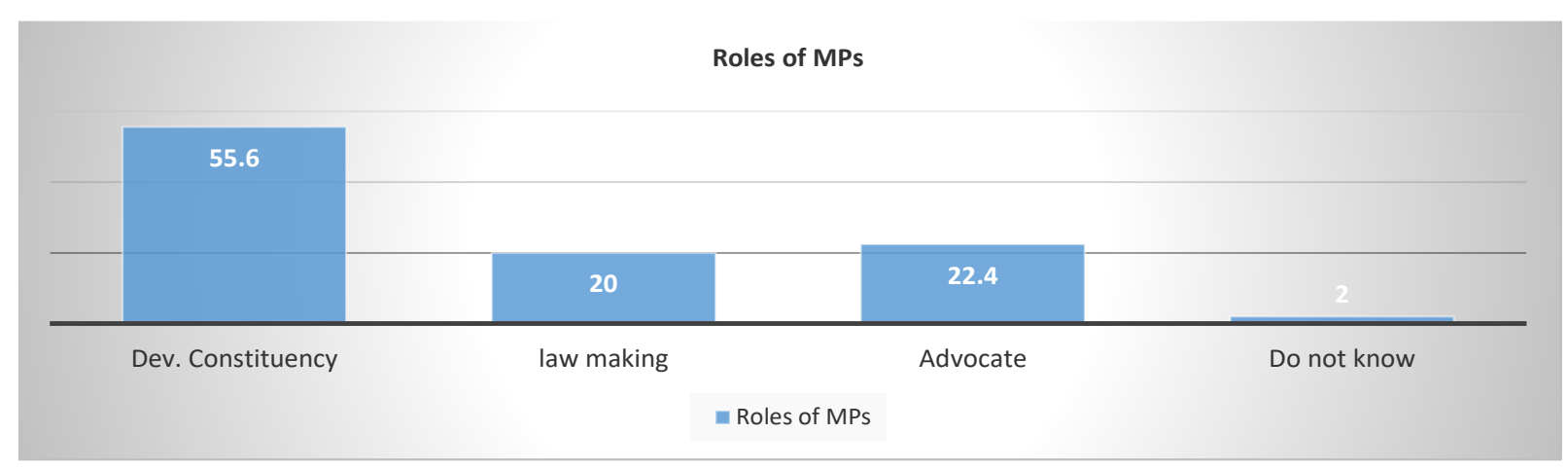

Figure 3. The respondents view on the role of MPs

The results illustrate that in Malaysia, the constituents consider that the main role of the MPs is to develop their constituencies. The constituents $(55.6 \%)$ believe that the main role of the MPs is to develop constituency economically. This perception indicates that the MPs are the persons that the constituents should approach for any problems in the community. The voters mention that bringing and stimulating the development into the constituencies is the main role of the MPs that would influence the constituents' perception. Notably, this finding is not new. There have been a few works that have mentioned how the development of the constituencies has been the major factor that influence the perception of the constituents towards their representative roles (Judge, 1999; Narud \& Valen, 2000). The MPs are also regarded as the spokespersons to represent the interests of the constituencies.

The second most popular representational role is being an advocator in order to ensure that the government is accountable for its action. This role is supported by $22 \%$ of the respondents. The advocacy role of the MPs refers to the support of citizens' concerns by advocating the issue or agenda in the Dewan Rakyat. However, the voters perceive that this role is not as important as the developing constituencies. In Malaysia, there is always the tendency that the government would proceed with the agenda even though the citizens require a better explanation in terms of accountability and transparency of the government's planning. As the mass media has always been heavily controlled by the government (Mohd Azizuddin, 2005; Rosyidah 2016), therefore, the opposition MPs have become the best mechanism for the citizens to channel their frustration with the government policy. The citizens hope that the MPs could ensure that the government is accountable for its action, and most often this role is carried out by the opposition party. Most of the MPs from the ruling party have to obligate to the party's rule and thus this may restrict them to advocate strongly in parliament. As such, the voters probably perceive this role to be the least important role for MPs, as not all MPs are able to advocate on the issue of the citizens' interest.

Formulating laws in parliament is regarded as the least important role of the MPs. Only $20 \%$ of the respondents chose this role as an important role of the MPs. This data is regarded as low since the primary role of the MPs is making laws in the parliament. Theoretically, MPs have the mandate that is given by the citizens to draft and to debate bills in parliament and they may support, oppose or remain neutral when the bills are tabled. In Malaysia, the situation is quite different. According to Aziz (2012), the Malaysian Parliament does not act as an effective overseeing body; the Malaysian Parliament has been weakened gradually in its capacity to check 
and balance executive power. He further states that, even when the MPs raise an issue relating to the citizens, they do not have the power to influence the final decision of the cabinet. Perhaps, this scenario might have influenced the perceptions of the voters in perceiving that making laws is not a primary role of the MPs since it is more of a top-bottom approach.

Development of the constituency is the most popular role that concerns the MPs. This can be described as being close to the delegates' model. This role concerns the demand for political representatives to keep fairly close to the opinions of the voters and to act according to them, particularly in the development of their constituency, while formulating laws is regarded to be the least important role of the MPs. This role resembles the 'Trustee Model' as MPs should act in the best interest of the public as a whole nation, corresponding with the use of their own common sense such as formulating laws. Interestingly this pattern is revealed when accounting for support on the MPs' role: the role of the MPs as being focused on the development of the constituent and is the most dominant, rather than in formulating laws.

\section{Satisfaction with the performance of MPs}

The finding of this study shows that more than half of the voters are satisfied with their respective MPs, where $53 \%$ of the voters express their satisfaction towards their MPs' performance, while the remaining of the $47 \%$ is not satisfied with their MPs. A considerable number of voters are satisfied because the MPs' effort in dealing with and providing for the constituents' needs is based on constituency works. This finding is also consistent with Aziz (2012) who argues that MPs can be labeled as social workers due to their efforts to meet with constituents' expectation such as attending wedding ceremony and others.

\section{Contacting MPs}

For the MPs to effectively represent the views of their constituents in the Malaysian Parliament, they must frequently interact with them. However, the findings indicate that MPs have made less contact with the constituents at the grassroots. Figure 4 shows that 385 (64.4\%) respondents claim that they have never contacted their representatives. Only 82 respondents $(13.7 \%)$ and 30 respondents $(5 \%)$ have contacted their MPs once and almost every month, respectively. Findings show that there are a few reasons that have influenced the tendency of the constituents to contact their MPs. A majority of 371 respondents (62\%) mention that they do not contact their MPs since they have nothing to deal with. Meanwhile, 57 respondents $(9.5 \%)$ state that they contact the MPs to ask about the development in their constituency, while 42 respondents $(7.0 \%)$ claim that they contact the MPs for financial support. The remaining 10 respondents (1.7\%) state various reasons for contacting their MPs.

The respondents were also asked the amount of time that they wanted their MPs to spend at constituency level. $43 \%$ of the constituents would like their MPs to visit them at least once a month, $12 \%$ of the constituents wanted their MPs to do so once a year, $7 \%$ stated every week and $16 \%$ for every time. Only $5 \%$ of them stated that they did not want their MPs to spend their time with the constituents, however, this contradicted the actual MPs who did spend their time with constituents. $28 \%$ of the constituents noted that MPs only spent their time with the constituents during an election; $11 \%$ claimed that they had only met their MPs once in two years; $10 \%$ and $9 \%$ of them had met their MPs once a month and once a year, respectively. A majority of them of i.e., 
$42 \%$ did not know whether their MPs had been to their constituency. This finding indicates that the constituents hardly have an opportunity to meet and greet their MPs except during the election campaign. The result showed that MPs still rarely spent their time in their constituencies. That is to say there is a huge gap between the constituents' expectation of their MPs presence at the constituency level and the political reality in Malaysia. Interestingly, despite the lack of the MPs presence at the constituency level, the constituents (65\% of the respondents) know and correctly identified their MPs.

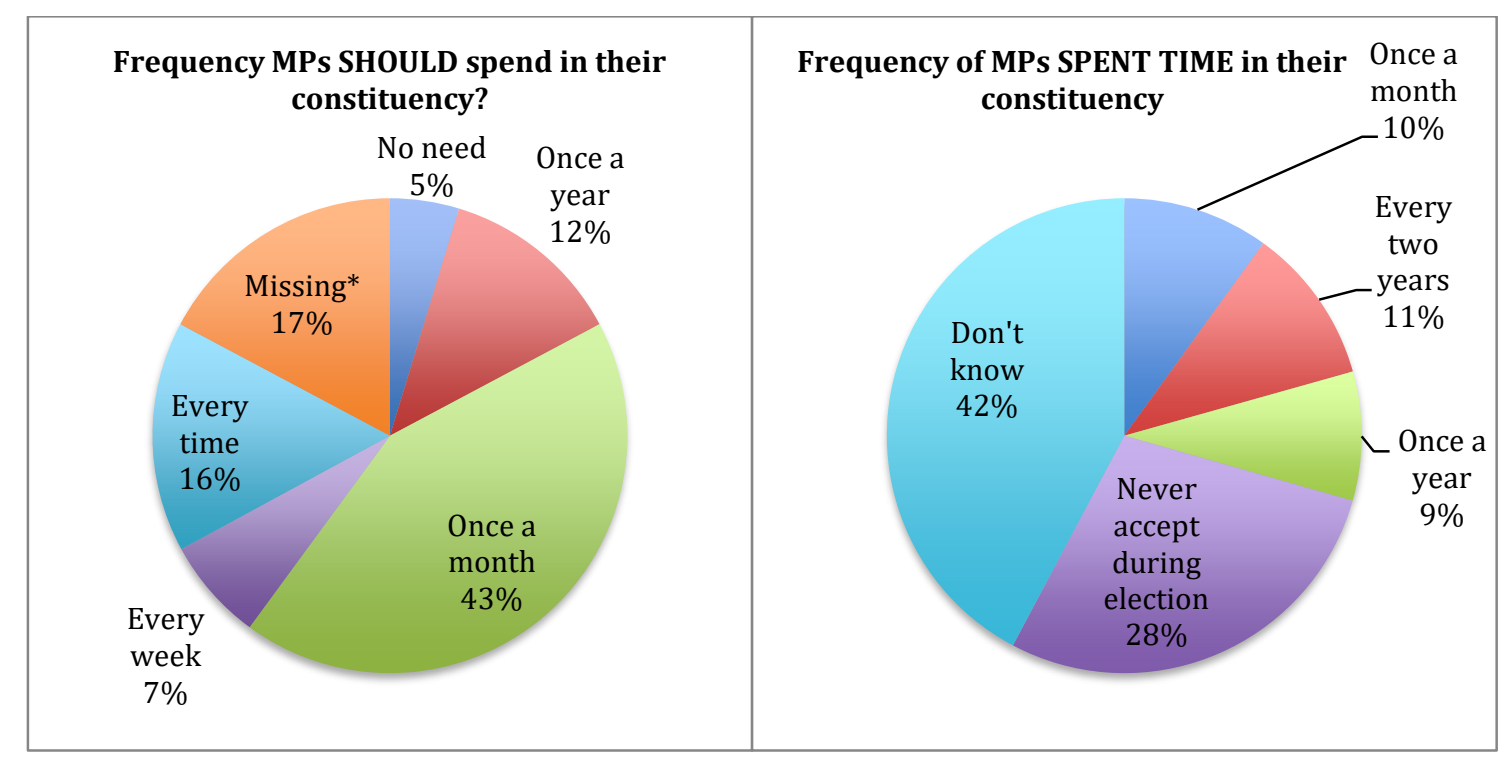

Figure 4. Frequency MPs SHOULD spent and MPs SPENT TIME in their constituency.

\section{Conclusion}

MPs are important agents to connect the Malaysian citizens with their government. This paper shows that the relationships between the citizens and their MPs are inconsistent in Malaysia. Although, the citizens are fairly satisfied with the performance of their MPs, they are ill-informed of the official roles and functions of the MPs. Overall, only 30\% of the respondents have good knowledge of the formal roles and functions of the MPs. To the citizens, the most important function of the Malaysian MPs is to bring development to their constituencies. The citizens' expectations mostly concentrate on the MPs spending most of the time at the constituency level, to solve constituent problems and to defend citizens' interests- on this end, more expectations are for the MPs assemble to delegate model. For them, the MPs are the mouthpiece of their constituency and should act only in the way their constituents would want them to; the legislator role- such as debating, making decision and passing laws, is considered to be of lesser importance. Voters may consider that such a role is for the cabinet or the executive branch's responsibility. For them, the MPs serve more as delegates who sort out the problems of the constituents rather than as trustees who represent a whole nation.

The findings in this study are similar to a few recent studies that have been undertaken empirically. The Malaysian MPs felt compelled to carry out duties of the local government, the welfare department and the state assemblymen in fulfilling the citizen's expectations and to stay relevant at the constituency level (Aziz, 2012). While a majority of the citizens is satisfied with 
the MPs performance at the constituency level, the biggest challenges of the MPs are to educate the citizens of their former roles and functions, in particular as the legislator in the Dewan Rakyat of the Malaysian Parliament. Ideally, the Malaysian MPs should focus on their main tasks of policy making, to actively participate in the parliamentary debates and represent their constituencies on national issues; the MPs should take the local issues for national policies implication or the national policies to be contextualized in their respective local constituencies. Only then, will the quality of representation in the Malaysian Parliament can be enhanced and improved.

\section{Acknowledgements}

This article is a part of the research which was funded (FRGS-54412) by Ministry of Higher Education (MOHE). The authors would like to express their gratitude to MOHE for the funding.

\section{References}

Akirav, O. (2020). Assessing the parliamentary activities of UK MPs. Br Polit, 15, 201-225. https://doi.org/10.1057/s41293-019-00111-w

Abdul Rashid, M. (2009). 2004 and 2008 General Elections in Malaysia: Towards a multicultural, bi-party political system?. Asian Journal of Political Science, 17(2), 173-194.

Aziz, N. (2012). Deliberative Practices in \& outside the Malaysian Parliament (Doctoral dissertation). Retrieved from research space Auckland University https://researchspace.auckland.ac.nz/bitstream/handle/2292/20731/whole.pdf;sequence=2

Bengtsson, A., \& Hanna, W. (2011). The representative roles of MPs: A citizen perspective. Scandinavian Political Studies, 34(2), 143-167.

Brouard, S. , Costa. O., Kerrouche, E., \& Schnatterer, T. (2013). Why do French MPs focus more on constituency work than on parliamentary work?. The Journal of Legislative Studies, 19(2), 141-159.

Crouch, H. (1996). Government and society in Malaysia. Ithaca: Cornell University Press.

Fox, J., \& Shotts, K. (2009. Delegates or trustee? A theory of political accountability. The Journal of Politics, 71(4), 1225-1237.

Heywood, A. (2004). Political Theory: An Introduction. New York,Palgrave, Macmillan.

Hwang, I.-W. (2003). Personalized Politics: The Malaysian State Under Mahathir. Singapore: Institute of Southeast Asian Studies.

Judge, D. (1999). Representation: theory and practice in Britain. Routledge, London; New York.

Lusoli, W., \& Ward, S. (2004). Digital Rank-And-File: Party activists' perceptions and use of the internet. The British Journal of Politics and International Relations, 6(4), 453-470.

Malike, B. (2017). The roles of elected representatives in political parties: What's the challenges?. Asian Social Science, 13(6), 55-64.

Manin, B. (1997). The Principles of Representative Government. Cambridge: Cambridge University Press.

Marsh, N., \& Norris, P. (1997). Political representation in European Parliament. European Journal of Political Research, 32, 153-164.

Mendez-Lago, M., \& Martinez, A. (2002). Political representation in Spain: An empirical analysis of the perception of citizens and MPs. Journal of Legislative Studies, 8(1),63-90. 
Mohd Azizuddin, M. S. (2005). Media freedom in Malaysia. Journal of Contemporary Asia, 35(3), 341-361.

Narud, H. M., \& Valen, H. (2000). Does Bakground Matter? Social Representation and Political Attitudes. In K. Heidar \& P. Esaiasson (Eds.), Beyond Westminster and Congress: the Nordic experience. Columbus, Ohio: Ohio State University Press.

Pitkin, H. F. (1967). The concept of representation. Berkeley: University of California Press.

Rosyidah, M. (2015). Online opposition and elections in Malaysia. Asian Social Sciences, 11(10)

Tiffany Jones Miller. (2007). James Madison's Republic of "Mean Extent" Theory: Avoiding the Scylla and Charybdis of Republican Government. Polity, 39(4), 545-569.

Ummu Atiyah, A. Z. (2010). Women in the Malaysian parliament: Do they matter?. Intellectual Discourse, 18(2), 283-322.

Searing, D. D. (1985). The role of the good constituency member and the practice of representation in Great Britain. The Journal of Politics, 47(2), 348-381.

Wright, T. (2010). What are MPs for?. The Political Quarterly, 18(3), 298-308. 